\title{
BATSHEVA GOLDMAN-IDA
}

\section{KABBALAH AND ART: INTRODUCTION}

This interdisciplinary religion-and-visual culture issue invites us to look on kabbalah as a fruitful way to further infuse the fields of both religion and art history. Cast aside is the classic trope of comparing the artwork to the contemporary milieu by means of an iconographic analysis to make room for artists and artwork from different periods. This unique compilation, drawing on the vast knowledge and experience of its contributors, relates to Jewish ritual art, contemporary Jewish artists, and the graphic compendiums of kabbalah on a subjective and theurgic level. This approach is one I have promoted in my recent book Hasidic Art and the Kabbalah. ${ }^{1}$

We find that the fields of kabbalah and art in the twentieth and twenty-first centuries are inexorably intertwined, nurturing one another in ways that are both creative and unique. In this issue, we join with a current trend in academia to turn to objects and visual images as primary sources of historical and philosophical truths. This trend began with museum curators and conservators, and has now reached the major universities as a topic of its own. The Bard Graduate Center in New York is a leader in this kind of historical and sociological analysis of visual culture. ${ }^{2} \mathrm{~A}$ fall 2020 undergraduate course at the Parsons School of Design in New York is entitled "Objects as History."3 One university in Cambridge boasts, as a matter of course, that on its campus the study of history allows for "the handling of historical objects." ${ }^{4}$ Moreover, the Rijksmuseum and the University of Amsterdam have been developing the field of object history, and in 2018 held an interdisciplinary seminar on this topic led by

\footnotetext{
1 Batsheva Goldman-Ida, Hasidic Art and the Kabbalah (LeidenBoston: Brill, 2018)

2 Peter N. Miller, Cultural Histories of the Material World (New York: Bard Graduate Center, 2013); see book description: "While gathering some of the most interesting thinkers in their respective fields, the contributions also examine material culture through a historiographical lens, considering how the field slipped between disciplines in the twentieth century, and how it has become more prominent inside and outside the academy in the last twenty years or so. The book builds on the recent proliferation of studies of materiality to offer a different, theoretically coherent approach to
}

researchers, curators and conservators, historians, and scientists. ${ }^{5}$ The earliest foray in this direction was by Neil McGregor, then director of the British Museum, London, in his popular 2010 radio series A History of the World in 100 Objects, which encouraged many to turn to stories as explanatory tools for the study of objects. The present issue "Kabbalah and Art," seeks to further this trend with the presentation of path-breaking research on ritual objects, plastic arts, and visual images as they relate to kabbalah. This is their story, and they share a value as primary sources for learning about the social and historical milieu, and philosophical outlook, of their makers (scribes/copyists) as well as viewers. My thanks go out to the visionary Images Editors-in-Chief, Steven Fine, Margaret Olin, and Maya Balakirsky Katz, who have supported me throughout this process.

The issue paves the way for the next step in kabbalah and art research, exploring the perspectives of artists who have moved beyond the New Age synergy of the 1980s. These include artists Jonathan Leaman (b. 1954, London) and R. B. Kitaj (1932-2007). Leaman, who I present here for the first time, sought religious imagery outside of Christian iconography, and found the kabbalah to be a source "so esoteric as to encourage an infinite range of interpretation." ${ }^{\prime 6} \mathrm{He}$ is interested in haecceity, the "thisness" of things, that which makes objects unique. His approach to objects is not as symbols, attributes or metaphors, but as reifications, the visual or material expressions of thought. There is much to learn from his extraordinary paintings and his trajectory on objects as the key to unraveling the essence of ideas. The well-known artist Kitaj is

the topic. All across the humanities fields there is a new interest in materials and materiality." https://store.bgc.bard.edu/chmw/.

3 https://courses.newschool.edu/courses/PLHT1000.

4 https://aru.ac.uk/study/undergraduate/history.

5 "Museum Objects as Evidence: Approaches to the Material World" at the University of Amsterdam (July 9 - July 20, 2018), https://www.uva.nl/en/discipline/conservation-and-restoration/ education/summer-schools/objects-as-evidence/object-as-evidence. html\#anker-2018-approaches-to-the-material-world.

6 See Batsheva Goldman-Ida, "Jonathan Leaman: In Conversation," in this issue. See also Richard Morphet, "Against Dogma," in Jonathan Leaman (London: Beaux Arts, 2002), 63-72. 
shown by Mirjam Knotter, Chief Curator of the Joods Historisch Museum in Amsterdam, to have identified his late wife Sandra (1947-1994) with the Shekhinathe female presence of God according to the kabbalah. His erotic Los Angeles paintings focus on his reunion with her as a means of his own transition from earthly existence to death. ${ }^{7}$

The issue also introduces scholars who are building new databases for future research, such as that of the Ilanot Project. ${ }^{8}$ Here, its director, J. H. Chajes, in a ground-breaking article, shows the subtle infiltration and impact of Sabbatean thought on the imagery of a group of ilanot, the Lurianic sefirotic scrolls. ${ }^{9}$ Eliezer Baumgarten, the Project Research Fellow, reveals the original, anthropomorphic drawings of Divine parsufim ("faces"), painted by the multi-talented eighteenthcentury Rabbi Sasson ben Mordechai Shandukh of Baghdad. ${ }^{10}$ For contemporary artist Sandra Valabregue (b. Paris, 1972), such images as these serve as a springboard for her 2018-2020 series Androgynous (Fig. 1). ${ }^{11}$ Thus, we find a dynamic interplay of kabbalah and art through the sharing of digital databases, juxtaposing the fields of research and artistic work in a dynamic that is continually growing in intensity.

Indeed, this issue brings together scholars of kabbalah to discuss art, and art historians to discuss kabbalah, bringing collaboration to fields traditionally kept separate in scholarly publications. In 2001, Giulio Busi first coined the term "Visual Kabbalah,"12 but scholars continued to note the general resistance against studying the topic. Writing in 2004, Ithamar Gruenwald, who chaired the Department of Jewish Philosophy and the Program in Religious Studies at Tel Aviv University, complained that many Bible and Judaic scholars rejected the realms of magic, mysticism, and myth, and "by ignoring this," wrote Gruenwald,
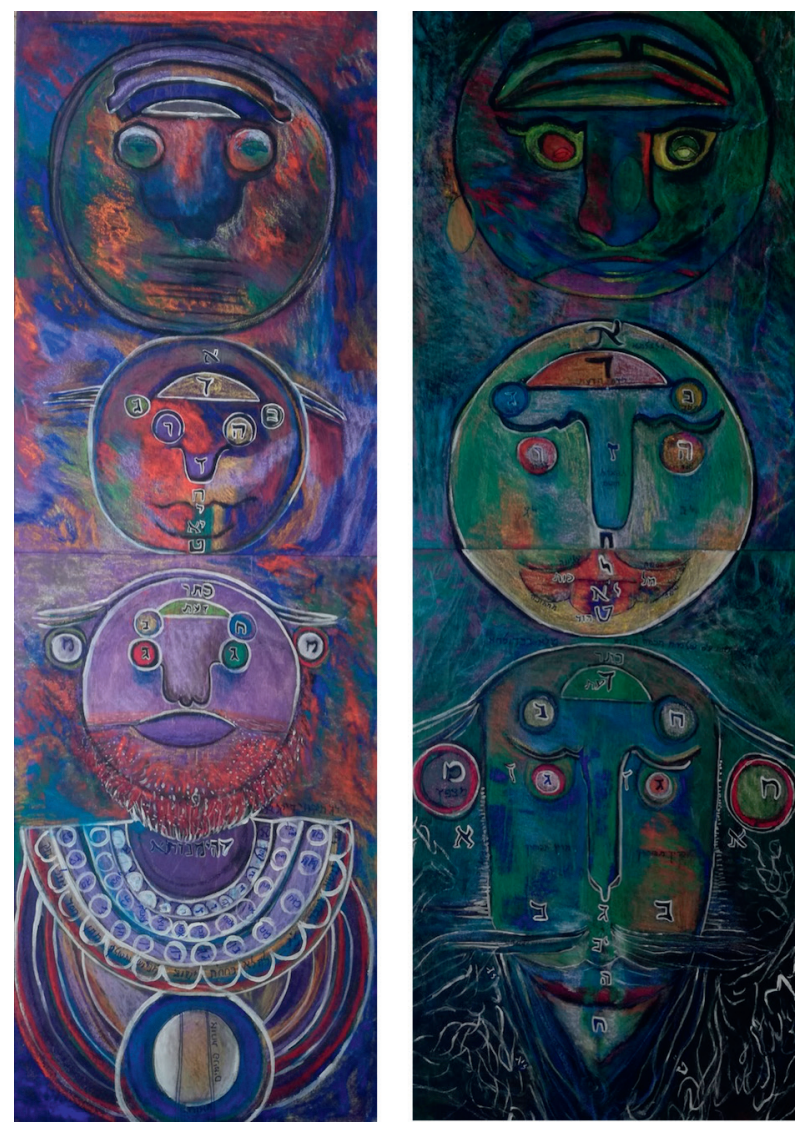

Fig. 1 Sandra Valabregue-Perry (b. Paris, 1972; lives and works in Jerusalem), A Sefirotic Tree II, Jerusalem, 2018, from the series Androgynous, pastel and ink on wood, diptych, $120 \mathrm{~cm} \times 40 \mathrm{~cm}$ each panel. Photo is courtesy of the artist.

"create a total distortion of the religious reality."13 In 2008, Yehuda Friedlander, former Rector of Bar-Ilan University and Professor of Hebrew Literature and Comparative Literature, expressed a similar dissatisfaction with the dearth of research in the realm of art and aesthetics. Friedlander wrote: "The elements of

\footnotetext{
7 See Mirjam Knotter, "From Angel to the Shekhina: The Influence of Kabbalah on the Late Work of R. B. Kitaj," in this issue. See also R. B. Kitaj, unpublished notes, entry dated December 1, 2003. (c) R. B. Kitaj Estate.

8 http://ilanot.haifa.ac.il/site/.

9 See J. H. Chajes, "Diagramming Sabbateanism," in this issue.

10 See Eliezer Baumgarten, "Faces of God: The Ilan of Rabbi Sasson ben Mordechai Shandukh," in this issue.

${ }^{11}$ See Figs, 9a and 9b, 10 in Baumgarten, op. cit., for comparison. Valabregue studied with Abraham Pincas (1945-2015) at the École nationale supérieure des beaux-arts (ENSBA) in Paris, and through him became interested in mysticism and kabbalah, later completing her dissertation under Professor Moshe Idel at the Hebrew University of Jerusalem. See Sandra Valabregue, Concealed and Revealed: "Eyn Sof" (Infinity) in Theosophic Kabbalah (Los Angeles:
}

Cherub Press, 2010); and Sandra Valabregue, "The Concept of Infinity (Eyn-sof) and the Rise of Theosophical Kabbalah," Jewish Quarterly Review 102, no. 3 (2012): 405-430. See also Abraham Pincas and Sandra Valabregue, La Source et le Nuage [The source and the cloud] (Paris: E.R.E.C, 2003). Valabregue keeps the two fields separate and concentrates on the materiality of the images rather than their meaning for her artwork. See recent Haifa University lecture series: Omanut ve'Yahadut: ha'yelhu shneihem yahdav? (Can Art and Judaism Coexist?), 3 (November 3, 2020): https://www.youtube.com/watch?v=Lb8Fgx7usjs [Hebrew].

12 See Giulio Busi, Qabbalah visive (Turin: G. Einaudi, 2005).

${ }^{13}$ Ithamar Gruenwald, "Myth and Historical Truth: Can Myths Be Shattered?" Myths in Judaism: History, Thought, Literature, ed. Ithamar Gruenwald and Moshe Idel (Jerusalem: The Zalman Shazar Center for Jewish History, 2004), vol. 2, 17-19 [Hebrew]. 
the aesthetic approach within Rabbinic thought have not yet been fully explicated as is required in the study of Jewish thought over the generations, and at times it appears to me as if there is a kind of elegant avoidance of confrontation with the subject."14 This issue is testimony to the progress that the fields of art and Judaic studies have made in the twenty-first century.

The current interest in art and spiritualism is evident in major exhibitions and events over the past decade: beginning with Traces du Sacré (Traces of the Sacred), Centre Pompidou (2008), through the "Speculatio mystica" session of the Salon Suisse at the 2015 Venice Biennale and my 2016 exhibition Alchemy of Words: Abraham Abulafia, Dada, Lettrism, ${ }^{15}$ to the renewed interest in 2019-2020 of artists Hilma af Klint (1862-1944) and Agnes Pelton (1881-1961). ${ }^{16}$ In her review of the major 2019 show Kabbalah: The Art of Jewish Mysticism in this issue, Judy Jaffe-Schagen discusses the ways in which museums display kabbalistic content as an "exhibited form of religion."17 An eyeopener for many is the role of the imagination in the homiletics of Rabbi Nahman of Bratslav (1772-1810). The leading scholar of Rabbi Nahman's thought, Zvi Mark, offers in his article here an explanation for the drive of many contemporary artists to view Rabbi Nahman as their muse. ${ }^{18}$

Kabbalah scholars Moshe Idel and Elliot Wolfson have published on Eros and kabbalah. ${ }^{19}$ Nevertheless, few in recent years have analyzed the homoerotic elements found in Jewish ritual objects. The important 1928 article from Freud's Imago journal by Jiří (Georg) Mordechai Langer (1894-1943) on the mezuzah, the Jewish doorpost scroll, published here in translation for the first time, opens new avenues of research that have long been neglected. ${ }^{20}$ A second object, the Hasidic square-round wedding ring, was intended for this issue. ${ }^{21}$ However, as we sought to delve deeper into the kabbalistic concept of the circle in the square, we found that the latent eroticism and esoteric nature of the texts were so great as to proscribe their presentation to the general public. Indeed, for many years, kabbalah was held as a secret science taught only to the select few.

Elliot Wolfson is a kabbalah scholar who is also an artist. His artwork is generally abstract and lyrical, expressing mood and thought. For Wolfson, it is a way to express the ineffable, a language beyond words (Fig. 2).22 In his essay which will appear in an upcoming issue, "Metaphor, Dream, and the Parabolic Bridging of Difference: A Kabbalistic Aesthetic," Wolfson examines the "footprints of the invisible in the field of the visible." ${ }^{23}$ An artist who later turned to kabbalah scholarship is Suzy Sitbon (1948-2014), who views the opening pages of a medieval manuscript as a diptych, tracing the kabbalistic significance of the geometric shapes of its micrography to the early mystical book Sefer Yetzirah (the Book of Creation). ${ }^{24}$ Whether her

18 See Zvi Mark, "Picture and Story: On the Use of Visual Imagery in the Writing of Rabbi Nahman of Bratslav" in this issue.

19 For example, Moshe Idel, Kabbalah and Eros (New Haven, CT: Yale University Press, 2005); and Elliot R. Wolfson, Language, Eros, Being: Kabbalistic Hermeneutics and Poetic Imagination (New York: Fordham University Press, 2005).

20 See Batsheva Goldman-Ida, "Introductory Remarks on Georg Langer's 'On the Function of the Jewish Doorpost Scroll' from 1928," followed by the original essay in translation, in this issue.

${ }^{21}$ Nurit Sirkis Bank, "The Square-Round Silver Wedding Ring," Ars Judaica: The Bar-Ilan Journal of Jewish Art 9 (2013): 101-110. See also See Elliot R. Wolfson, Circle in the Square: Studies in the Use of Gender in Kabbalistic Symbolism (Albany: SUNY Press, 1995).

$22 \mathrm{http} / / /$ wolfson.faculty.religion.ucsb.edu.

${ }^{23}$ See Elliot R. Wolfson, "Metaphor Dream, and the Parabolic Bridging of Difference: A Kabbalistic Aesthetic," forthcoming.

24 Suzy Sitbon, "Intersections between Artistic Visual Creation and Cosmogony in Some Spanish Bibles." Iggud: Selected Essays in Jewish Studies 3 (2005): 99-113, http://www.jstor.org/ stable/23533544. loie-hollowell/.

17 See Judy Jaffe-Schagen, "Displaying Mysticism: Another Look at Exhibition Design," in the review section of this issue. 


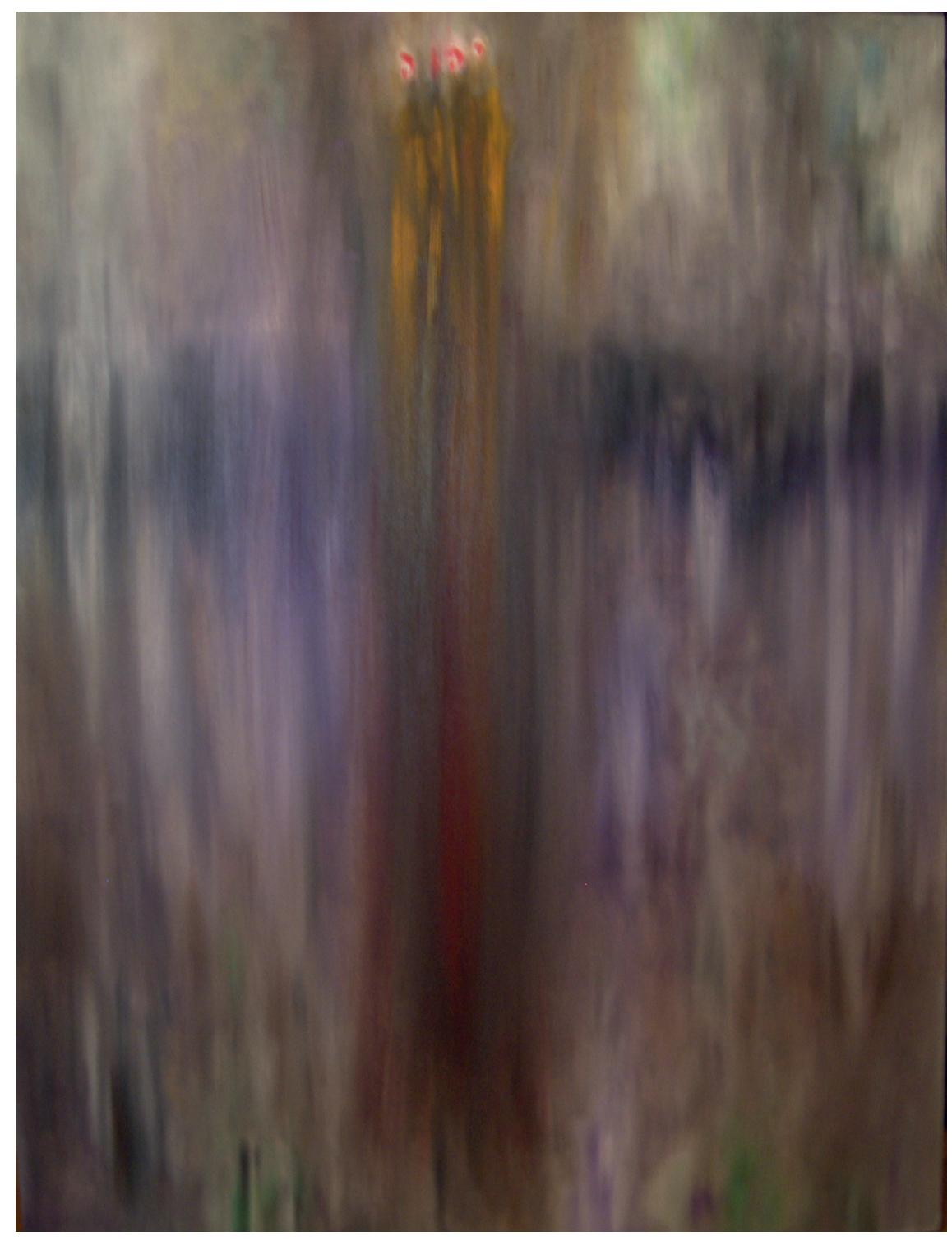

Fig. 2 Elliot R. Wolfson (b. Newark, New Jersey, 1956; lives and works in Santa Barbara, California), Parting Ways, New York City, 2009, oil on canvas, $36 \mathrm{~cm} \times 48 \mathrm{~cm}$. Photo is courtesy of the artist.

claim that these manuscripts were used by the 'Iyyun Group in thirteenth-century Provence can be corroborated, the suggestion that geometric shapes are found in numerical combinations of kabbalistic significance is a fascinating one that needs to be further investigated.

These are but a few of the intriguing aspects of contemporary research on kabbalah and art. We look forward to further research on this dynamic in the coming years.
Batsheva Goldman-Ida is an independent Curator and Art Historian with a specialty in the field of kabbalah and art. Her book, Hasidic Art and the Kabbalah, was published by Brill in 2018, and details eight Hasidic objects and their mystical significance. She is currently curating an exhibition of the performance and video artist Gregory Abou (b. Melun, France, 1974; lives and works in Tel Aviv), entitled JETESAIS ("I Know You"), to open in March 2021 at the Mishkan Museum of Art, Ein Harod, Israel. 